\title{
INOVASI PUBLIK PERSPEKTIF TRIPLE HELIX: STUDI DI KABUPATEN SUMBAWA NUSA TENGGARA BARAT
}

\author{
M. Firmansyah ${ }^{1}$, Agus Suman ${ }^{2}$ \\ ${ }^{1}$ Universitas Mataram, Mataram, firmansyah.feb@unram.ac.id \\ ${ }^{2}$ Universitas Brawijaya,Malang,agussuman@yahoo.com

\begin{tabular}{|c|c|c|c|}
\hline \multicolumn{4}{|l|}{ Article history } \\
\hline $\begin{array}{l}\text { Dikirim tanggal } \\
\text { Revisi pertama tanggal }\end{array}$ & $\begin{array}{l}: 08 / 02 / 2021 \\
: 16 / 08 / 2021\end{array}$ & $\begin{array}{l}\text { Diterima tanggal } \\
\text { Tersedia online tanggal }\end{array}$ & $\begin{array}{l}: \quad 18 / 08 / 2021 \\
: \quad 07 / 09 / 2021\end{array}$ \\
\hline
\end{tabular}

\begin{abstract}
ABSTRAK
Inovasi pembangunan saat ini menjadi instrumen yang terus didorong pemerintah pusat terhadap pemerintah daerah di Indonesia. Dengan inovasi, keterbatasan pembangunan dapat berjalan walau dengan anggaran terbatas. Penelitian ini menjelaskan pengembangan dan kendala inovasi berbasis triple helix di Kabupaten Sumbawa, Provinsi Nusa Tenggara Barat. Data terkait semua inovasi diperoleh dari proses wawancara dengan Bappeda Kabupaten Sumbawa dan beberapa sumber lain. Dari masing-masing inovasi akan dipilih yang mengandung unsur triple helix. O'Samawa adalah model inovasi triple helix berupa komunitas yang dibentuk berdasar MoU antara Bappeda Sumbawa, UTS (Universitas Teknologi Sumbawa) dan pelaku usaha. Tujuan O'Samawa adalah memfasilitasi pelaku usaha untuk meningkatkan kapasitas produk dan kemasan, mempermudah akses permodalan dan jaringan pasar. Kegiatan yang sudah dilakukan dalam O'Samawa adalah training, pameran produk, seminar, membangun gerai (toko) bersama dan membangun website pasar online.
\end{abstract}

Kata Kunci: Inovasi, Triple helix dan O’Samawa

\begin{abstract}
Development innovation is now an instrument that continues to be driven by the central government towards local governments in Indonesia. With innovation, the limitations of development can work even with a limited budget. This study describes the development and innovation constraints of triple helix based in Sumbawa Regency, West Nusa Tenggara Province. Data related to all innovations was obtained from the interview process with the Sumbawa Regency Bappeda and several other sources. From each innovation will be selected that contains the triple helix element from each of these innovations. O'Samawa is an innovation model in the form of a community formed based on an MoU between the Sumbawa Bappeda, UTS (Sumbawa Technology University) and business people. The goal of O'Samawa is to facilitate businesses to increase product and packaging capacity, facilitate access to capital and market networks. Activities that have been carried out in $O$ 'Samawa are training, product exhibitions, seminars, building a joint store (shop) and building an online market website.
\end{abstract}

Keyword: Innovation, Triple helix and O'Samawa 


\section{PENDAHULUAN}

Badan Perencanaan Pembangunan Nasional (Bappenas) RI menyelenggarakan Lomba Perencanaan Pembangunan Daerah (PPD) setiap tahun. Pesertanya Bappeda seluruh Indonesia, baik tingkat provinsi maupun kabupaten/ kota. Ada tiga aspek yang dinilai dalam lomba tersebut yaitu 1). Pencapaian pembangunan, seperti pertumbuhan ekonomi, tingkat pengangguran terbuka (TPT) dan kemiskinan, IPM, pelayanan publik, pengelolaan keuangan, transparansi dan capaian pembangunan secara spesifik daerah, 2). Proses penyusunan dokumen dalam musrembang dan RKPD. 3) Inovasi Daerah, dengan melihat jenis inovasi, prosesnya, input sampai outcome. Dalam menilai kinerja provinsi, juri dari pusat akan berkunjung untuk verifikasi data penunjang. Di level kabupaten dan kota akan dinilai juri tingkat provinsi. Setelah ditentukan pemenang pemenang, selanjutnya akan mewakili kabupaten dan kota di masing-masing provinsi di level nasional.

Unsur yang paling menarik untuk dikaji lebih jauh adalah inovasi daerah. Daerah berkreasi menghasilkan inovasi sesuai potensi sekaligus menjadi bagian meningkatkan kinerja pelayanan publik perangkat daerah. Sebagai contoh, di Bandung Jawa Barat kinerja camat dan lurah termuat dalam aplikasi Bdg Juara (Ella \& Utami, 2017), di Jakarta ada istilah suami siaga (Hill, Goeman, Sofiarini, \& Djara, 2014), di Kota Bogor terdapat program pos pemberdayaan keluarga, disingkat Posdaya (Alamsyah \& Fitriah, 2009), di Kabupaten Timur tengah Utara ada program Anggaran Rakyat untuk Menuju Sejahtera yang diistilahkan dengan Angur Merah (Tiza, Hakim, \& Haryono, 2014) dan di Semarang ada inovasi pusat informasi Leptopsirosis (Mahalul, H, \& Sugiharto, 2018).

Pengembangan inovasi saat ini terus dilakukan pemerintah daerah untuk melayani masyarakat. Tujuan dari inovasi mempermudah sistem informasi antara pemerintah dan masyarakat terkait pelayanan publik (Alamsyah \& Fitriah, 2009), meningkatkan kapasitas ekonomi (Mei \& Wang, 2017). Beberapa daerah menjadikan inovasi sebagai salah satu petunjuk sukses atau tidak pimpinan OPD dalam memimpin dinas. Di Cina terbukti inovasi terkait peningkatan kapasitas ekonomi lebih menjadi prioritas untuk dikreasikan dibanding peningkatan kapasitas sosial dan politik daerah, sehingga instrumen ekonomi menjadi tujuan capaian pemimpin di daerah (Mei \& Wang, 2017). Penelitian sebelumnya di Indonesia belum banyak memaparkan manajemen inovasi berbasis triple helix yang dikembangkan pemerintah daerah. Penelitian ini bertujuan:1) Menjelaskan berbagai inovasi yang dihasilkan kabupaten Sumbawa; 2). Menjelaskan awal lahirnya inovasi triple helix di Kabupaten Sumbawa; 3). Menjelaskan bentuk operasional dari inovasi triple helix dan perkembangannya;4). Mengidentifikasi kendala yang dihadapi dalam keberlanjutan inovasi triple helix.

\section{KAJIAN PUSTAKA}

Praktik inovasi dalam sektor publik diharapkan tetap tumbuh dan terpelihara dalam kerangka kerja pemerintah daerah. Inovasi diharapkan mampu meningkatkan kapasitas pelayanan publik, efisiensi, sekaligus meningkatkan pendapatan masyarakat dan daerah, dengan membantu meningkatkan kapasitas bisnis. Di Indonesia, inovasi terus didorong pemerintah pusat untuk terus diperluas. Dalam RPJMD (rencana pembangunan jangka menengah daerah) masing-masing pemerintah daerah bersemangat menonjolkan inovasi. Pemerintah pusat dalam hal ini Bappenas menjadikan inovasi sebagai salah satu penilaian prestasi perencanaan pembangunan daerah (PPD).

Tujuan dari kebijakan inovasi adalah melahirkan kelembagaan dan menjadi penghubung dari setiap jaringan (Jauhiainen \& Suorsa, 2009). Sehingga demikian dibutuhkan keragaman ilmu pengetahuan dari berbagai aktor di dalamnya (Yarime, 2018). Inovasi akan lahir dan terpelihara ketika masing-masing terbagi peran di antara stock holder dan secara sosial dipelihara sejalan dengan dipeliharanya budaya pengembangan ilmu pengetahuan. Sehingga, dalam menciptakan inovasi, tidak saja dibutuhkan pengetahuan teknis industri, bisnis namun juga pengetahuan rekayasa sosiologis dan budaya. 


\section{Inovasi dalam Triple helix}

Dalam literature terkini, pembahasan inovasi kebijakan publik banyak berkaitan dengan konsep triple helix (misal: Altaf, Hassan, \& Batool, 2019; Etzkowitz \& Zhou, 2017; Guerrero \& Urbano, 2017; Hughes, 2014; Pique, Berbegal-Mirabent, \& Etzkowitz, 2018; Reich-Graefe, 2016; Sato, 2017; Smith \& Leydesdorff, 2017; Verlinde \& Macharis, 2016). Di dalamnya membahas inovasi sosial (Paskaleva \& Cooper, 2018), kemitraan harmonis antara akademisi, industri, pemerintah daerah dan masyarakat sipil (Yarime, 2018), intervensi pemerintah (Wang, 2018) serta kendala pendanaan dan administrasi (Oganisjana \& Gvatua, 2017). Namun yang pasti, tujuan dari triple helix adalah untuk menyelesaikan masalah dalam masyarakat (Verlinde \& Macharis, 2016).

Triple helix diartikan sebagai bentuk interaksi dalam melahirkan inovasi antara universitas, industri dan pemerintah (Etzkowitz \& Zhou, 2017). Salah satu contoh model triple helix yaitu antara Universitas Stanford, industri dan pemerintah yang menghasilkan "Silicon Valley"(Etzkowitz, 2017). Universitas dengan kapasitas keilmuan yang dimiliki dianggap mampu melahirkan produk-produk baru sesuai jaman, sementara itu industri merupakan pengguna (user) dari inovasi. Pembangunan Sains Techo Park, Lembaga transfer teknologi, pusat pengembangan inovasi serta program spin off bisnis adalah langkah yang diambil pemerintah Rusia pada masa transisi setelah Uni Soviet runtuh (Leydesdorff, Perevodchikov, \& Uvarov, 2015), di samping itu, peran pemerintah adalah mengembangkan litbang dan pembangunan inovasi (Wang, 2018).

Diskusi triple helix tentu tidak lepas dari kultur atau kebiasaan masyarakat. Dalam ilmu ekonomi, ilmu yang mempelajari aspek kebiasaan dan rutinitas adalah disebut institutional economics. Kajian peran kelembagaan ekonomi yang dikaitkan dengan triple helix masih sangat terbatas. Variasi produk industri terus berkembang sejalan dengan perkembangan teknologi. Sehingga pola interaksi dalam triple helix terus mengalami perkembangan diakibatkan peran agen yang berkembang setiap waktu (Pique et al., 2018). Dengan demikian, pembahasan inovasi harusnya tidak berhenti pada proses interaksi yang melahirkan produk-produk baru, namun juga menjaga awet-nya interaksi tersebut. Sustainability inovasi memang menjadi pertimbangan penting dalam produk inovasi. Oleh karenanya, inovasi dalam ekosistem (Pique et al., 2018) sama pentingnya dengan inovasi dalam produksi.

Paskaleva \& Cooper menganggap bahwa inovasi layanan perlu integrasi antara teknologi dan inovasi sosial dengan dukungan kapasitas dan keahlian yang memadai (Paskaleva \& Cooper, 2018). Sehingga triple helix harus ditarik ke dalam peran masyarakat sipil selain industri, pemerintah dan perguruan tinggi (Yarime, 2018). Di samping itu, peran program untuk penyelesaian berbagai masalah dalam masyarakat sebagai bentuk inovasi juga merupakan jalan yang tepat untuk merawat inovasi (Hutagalung \& Hermawan, 2018).

Persoalan birokrasi menjadi salah satu penyebab dari tidak dirawat-nya inovasi, di samping pasif-nya peran masyarakat (Oganisjana \& Gvatua, 2017). Menurut Oganisjana \& Gvatua (2017) jalan yang ditempuh dalam merawat inovasi adalah dengan gencar melakukan promosi yang di dalamnya termasuk memberi pengetahuan pada masyarakat, mengarahkan partisipasi semua pemangku kepentingan, melakukan aktualisasi masalah dan solusi yang dihadapi masyarakat.

Hubungan antara universitas dengan pelaku bisnis tidak selamanya berjalan beriringan. Dua entitas ini dihadapkan dengan kepentingan masing-masing. Satu sisi perguruan tinggi berkepentingan dengan produk riset ilmiah dibandingkan nilai bisnis sedangkan perusahaan lebih mengutamakan keuntungan bisnis. Dua arah yang berbeda ini perlu dibangun kesepakatan Bersama, dengan demikian perlu ada komunikasi dan interaksi yang baik (Altaf et al., 2019) dalam rangka menyatukan dua pola tersebut. Langkah idealnya, aspek komersialisasi yang mengedepankan efisiensi tidak mendegradasi kajian ilmiah yang mungkin sangat mahal dan tidak efisien dari perspektif bisnis.

\section{Memupuk inovasi}

Menurut Carbonara \& Pellegrino (2018) sektor swasta perlu terlibat lebih jauh dalam rangka meningkatkan inovasi. Lebih jauh hasil studi menunjukkan dominasi perusahaan berskala besar berkorelasi positif dengan output inovasi (Carbonara \& Pellegrino, 2018). Hal ini dapat 
dimaklumi, bahwa perusahaan besar dengan tingkat persaingan yang ketat diperlukan langkah inovatif dalam menciptakan produk.

Tidak saja faktor internal perusahaan yang mempengaruhi inovasi, faktor eksternal juga berperan penting mendorong inovasi. Studi Sabry (2018) menunjukkan Asosiasi Bisnis yang kuat hubungan bisnis dan negara serta reformasi kelembagaan diperlukan dalam meningkatkan inovasi(Sabry, 2018). Penelitian Sabry dilakukan di MENA (Middle East North Africa). Sementara itu dalam perspektif makroekonomi seperti populasi, pertumbuhan ekonomi, rendahnya pengangguran akan mudah lahir inovasi(Nelson \& Svara, 2012).

Dalam merawat inovasi yang sudah terbentuk menjadi tantangan tersendiri bagi pemangku kepentingan. Inovasi yang telah berjalan dibutuhkan bahan bakar untuk terus tetap hidup. Masalahnya, budaya birokrasi belum cukup memberi perhatian terhadap program yang sudah dijalankan, karena dihadapkan dengan perubuhan kebijakan, perubahan program akibat perubahan struktur jabatan. Sehingga demikian, dalam meningkatkan peran triple helix dalam pembangunan dibutuhkan aturan berupa perda atau peraturan kepala daerah yang memastikan bahwa siapa pun pejabat yang menangani triple helix road map pembangunan ekonomi pengetahuan triple helix dapat terus berlanjut.

\section{METODE PENELITIAN}

Penelitian ini merupakan penelitian kualitatif. Inti dari metode kualitatif adalah wawancara mendalam terhadap individu atau kelompok kecil, observasi perilaku secara sistematis dan analisis dokumen (Darlington \& Scott, 2002). FGD dilakukan di kantor Bappeda saat dilakukan penilaian Perencanaan Pembangunan Daerah (PPD) untuk kabupaten Sumbawa. Kebetulan penulis merupakan salah satu juri dari lomba tersebut. Di samping itu, peneliti melakukan wawancara terhadap penggagas konsep triple helix di Sumbawa. Ada dua orang, satu berinisial DD pegawai Bappeda Kabupaten Sumbawa dan ke-2 berinisial J A dosen Universitas Teknologi Sumbawa. J.A saat itu tengah menyelesaian studi master di Eropa, sehingga dilakukan wawancara secara daring.

Di samping hasil wawancara, data juga diperoleh dalam bentuk dokumen, terutama terkait RKPD (Rencana Kerja Pemerintah Daerah) Kabupaten Sumbawa yang memuat inovasi daerah. Data terkait implementasi lapangan diperoleh peneliti di media masa. Tahap selanjutnya, Peneliti melakukan sortir data. Dari dokumen itu peneliti melakukan pengkajian untuk memastikan apakah inovasi tersebut berkaitan dengan triple helix. Semua inovasi yang merupakan produk Kabupaten Sumbawa dijelaskan dalam studi ini, kemudian peneliti memilih di antara inovasi tersebut yang berkaitan dengan inovasi triple helix. Analisis data dilakukan secara narrative kualitatif. Tujuan analisis naratif adalah mengurai sejarah atau kronologis awal pembentukan triple helix dan saat berjalan beserta tantangan dan berbagai hambatannya berdasar pengalaman informan.

\section{HASIL DAN PEMBAHASAN}

\section{Inovasi Kabupaten Sumbawa}

Setidaknya ada empat program yang dianggap sebagai inovasi dari Kabupaten Sumbawa, yaitu diistilahkan dengan Pariri si Desa, O'Samawa, Si Andini dan Si jinak. Pariri Si Desa adalah bentuk pelayanan terintegrasi satu hari di setiap desa. Pariri Si Desa merupakan program inovasi pelayanan publik, yang dihajatkan untuk mendekatkan pelayanan publik di bidang pemerintahan, kesehatan, pendidikan, KB, penataan lingkungan dan pariwisata kepada masyarakat di Kecamatan Lantung Kabupaten Sumbawa (RRI, 2018). Inovasi Pariri Si Desa murni dikembangkan oleh pemerintah. Tujuannya mempermudah masyarakat mengakses pelayanan publik.

Si Andini merupakan kepanjangan dari Sistem Antisipasi Dini Inflasi Daerah. Program si Andini juga diakui sebagai inovasi yang dihasilkan Kabupaten Sumbawa. Semangat awal munculnya Si Andini merupakan tanggapan dari pentingnya upaya kelola inflasi dalam pembangunan dan pengentasan kemiskinan. 
Pencatatan inflasi di Provinsi Nusa Tenggara Barat oleh BPS (Badan Pusat Statistik) dilakukan pada dua daerah, yaitu Kota Mataram di pulau Lombok dan Kota Bima di Pulau Sumbawa. Mengingat tidak tersedia data inflasi di Kabupaten Sumbawa, Pemerintah Kabupaten Sumbawa berinisiatif mengembangkan sistem pencatatan inflasi sendiri sekaligus membangun perangkat berbasis online. Dengan demikian, tujuan aplikasi si Andini adalah memberi layanan informasi harga kebutuhan pokok bagi masyarakat Sumbawa dan memberi peringatan dini pada pemerintah untuk melakukan antisipasi ketika terjadi inflasi. Di samping melakukan pencatatan, pengelola si Andini melakukan analisa forecasting trend perkembangan inflasi ke depan.

Situs si Andini http://siandini.sumbawakab.go.id dapat diakses secara bebas. Manfaat Si Andini di samping menghindari data hoax tentang inflasi, juga memberi kepastian harga pada konsumen. Tahapan proses sistem si Andini: 1). Bupati menerbitkan SK sebagai legalitas pembentukan tim kerja, dalam hal ini SK Bupati Sumbawa No. 201 tahun 2018 Tentang Tim Pemantauan dan Analisa Harga. 2). Tim akan bekerja mencatat dan menganalisis terjadinya pergerakan harga. 3). Aplikasi akan mengirim signal peringatan dini ke gadget atau hand phone bupati dan TPID untuk dianalisis lebih lanjut.

Si Jinak. Si Jinak merupakan kepanjangan dari sistem Jaringan informasi Ternak (SuaraNTB, 2018). Si Jinak dikembangkan untuk mengikuti perkembangan dunia IT (informasi teknologi) dalam perdagangan ternak. Sebelumnya pendataan ternak dilakukan secara manual, sehingga dianggap tidak efisien. Kehadiran si Jinak dapat memberi kepastian terhadap pendapatan $\mathrm{PAD}$, data populasi ternak dan jumlah ternak legal dan ilegal yang dikirim keluar. Website Si Jinak dapat diakses melalui http://sijinak.sumbawakab.go.id/Auth dengan terlebih dahulu melakukan login.

\section{Inovasi Triple helix di Sumbawa}

Dari ketiga inovasi tersebut di atas belum merupakan penerapan konsep triple helix. Di mana pengembangan hanya secara parsial oleh pemerintah daerah, belum ada kontribusi nyata dari sektor bisnis dan kampus. Penerapan model triple helix di Kabupaten Sumbawa adalah aplikasi perdagangan yang disebut "O-Samawa".

Tujuan program ini adalah untuk menyinergikan antara pemerintah kabupaten, dunia usaha dan universitas. Keterlibatan pemerintah daerah secara spesifik adalah oleh Dinas Diskoperindag dan Bappeda Sumbawa. Sedangkan sektor bisnis diwakili oleh BRI Cabang Sumbawa sebagai institusi keuangan, PT. Olas Maras Teknologi, PT. Wastec Internasional dan PT. Maras Mining Tech. Sedangkan Universitas diwakilkan oleh UTS (Universitas Teknologi Sumbawa) atau kelas wirausaha UTS. Di samping itu terlibat di dalamnya komunitas Penjual Tenun Ikat Sumbawa, UMKM-K Sumbawa dan 20 Bumdes di 20 desa di Sumbawa. O'Samawa merupakan gerakan sosial, dengan mengintegrasikan peran berbagai pihak.

Mengacu pada pihak yang terlibat dan penerima manfaat langsung dari inovasi tersebut maka, O'Samawa merupakan inovasi yang memberi kemanfaatan lebih luas bagi ekonomi Kabupaten Sumbawa. Adapun perbandingan pihak yang terlibat dan penerima manfaat dari inovasi dituang dalam tabel di bawah ini.

Table 1.

Jenis Inovasi Kabupaten Sumbawa, Pihak yang Terlibat dan Penerima Manfaat Langsung

\begin{tabular}{clll}
\hline No & \multicolumn{1}{c}{$\begin{array}{c}\text { Jenis } \\
\text { Inovasi }\end{array}$} & \multicolumn{1}{c}{ Pihak yang Terlibat } & \multicolumn{1}{c}{ Penerima Manfaat Langsung } \\
\hline 1 & Pariri Si & Pemerintah Kecamatan Lantung & Masyarakat Kecamatan Lantung \\
& $\begin{array}{l}\text { Desa } \\
\text { Si Andini }\end{array}$ & $\begin{array}{l}\text { Sumbawa. } \\
\text { Bappeda Kabupaten Sumbawa. }\end{array}$ & $\begin{array}{l}\text { Pemerintah, pendagang dan } \\
\text { konsumen (masyarakat) }\end{array}$ \\
3 & Si Jinak & Dinas Peternakan. & $\begin{array}{l}\text { Peternak dan pedagang Sapi } \\
\text { Belaku usaha (akselerator bisnis), }\end{array}$ \\
4 & O`Samawa & $\begin{array}{l}\text { Bappeda Sumbawa, Pelaku } \\
\text { Bisnis (UKM dan jasa Keuangan) } \\
\text { dan Kampus (UTS) }\end{array}$ & $\begin{array}{l}\text { Start-up (wirausaha baru) dan } \\
\text { masyarakat secara luas (konsumen) }\end{array}$ \\
& &
\end{tabular}

Sumber: Dari berbagai Sumber. 


\section{Inovasi lahir di Ruang Santai}

Kelahiran O'Samawa disebabkan banyak ruang publik kreatif (RPK) tidak digunakan sebagaimana mestinya. Padahal RPK di Sumbawa mumpuni untuk memacu inovasi, hanya belum ada yang memulai. Lebih jauh menurut penggagas O'Samawa, persoalan UMKM di Sumbawa umumnya pasar tidak luas dan tidak ada networking, maka komunitas O'Samawa melakukan sinergi ABGC yaitu Academic (Universitas Teknologi Sumbawa), Bisnis: Perbankan, Government-nya Pemerintah Kabupaten Sumbawa dan C pengrajin. O'Samawa membangun system from community to government.

Inovasi O'Samawa lahir dari ruang-ruang informal dalam suasana santai, tidak lahir di atas meja kerja formal yang penuh dengan kekakuan dan program yang terstandar. Suasana santai dan penuh keakraban menjadi jalan untuk menggapai inovasi. Sehingga pemerintah daerah sulit menciptakan inovasi bila ruang-ruang keakraban publik tidak dipelihara.

O'Samawa lahir dari pertemuan di kafe-kafe dalam membicarakan pengembangan bisnis oleh start up. Semakin lama komunitasnya berkembang (DD, Bappeda Sumbawa)

Anak-anak muda ini diundang untuk ekspos produk, menyusun data base, buat vlog. Semakin lama kegiatan mereka semakin asyik (DD, Bappeda Sumbawa)

Program yang menciptakan suasana santai semacam ini sulit diharapkan lahir dari pemerintah. Pemerintah dalam setiap perancangan program harus memenuhi kaidah perencanaan seperti adanya payung hukum, adanya output dan outcome yang standar dari setiap program. Program yang akan dieksekusi disiapkan dalam penyusunan renstra (rencana strategis). Sehingga sangat tepat bila pemerintah daerah cukup memfasilitasi lahirnya dan berkembangnya inovasi tanpa harus menjadi bagian untuk mengurusi kelembagaan di dalamnya.

Pemerintah fasilitasi diskusi-diskusi positif kalangan muda, mengadakan lomba bisnis plan dan prototipe produk. Di samping itu, pemerintah daerah fasilitasi kerja sama antar dunia usaha, lembaga keuangan dan kampus. Pemerintah daerah juga menyiapkan lokasi untuk pengembangan bisnis, workshop start-up serta membantu dalam pembiayaan kemasan, pameran dan seterusnya.

Pemerintah Kabupaten Sumbawa banyak fasilitasi kegiatan O'Samawa dan memperkenalkan O'Samawa dengan melakukan bisnis expo yang melibatkan puluhan UMKM, kampus UTS dan pemerintah dengan tema akselerator bisnis dan expo produk tau samawa (tanah samawa). Lanjutnya, kegiatan yang merupakan tindak lanjut MoU antara UTS dan Bupati Sumbawa tersebut, saat ini sudah membantu 27 Pelaku Industri Rumah Tangga. Selain itu, juga dilakukan inovasi kemasan pada 20 produk Bumdes yang menjadi komunitas binaan, dan menghasilkan 10 produk lokal inovasi anak muda Sumbawa yang berasal dari desa Lantung dan Empang.

\section{Bentuk-Bentuk Kerja Sama}

Bentuk kerja sama antara stockholder dalam komunitas O'Samawa adalah dengan membangun akselerasi untuk UMKM. Ada beberapa kegiatan yang telah dilakukan, yaitu training dari pelaku start up dan bank ke UMKM kerjasama antara bank dengan UMKM untuk pinjaman kemitraan dengan bunga 3 persen, kerjasama marketing. Bahkan O 'Samawa punya kantor tempat UMKM berjualan yaitu di gedung yang disebut UPT. Batik di Kabupaten Sumbawa.

Di samping kerjasama dengan pemda digalakan, Diskoperindag (Dinas Koperasi dan Perindustrian) terus melakukan akselerasi kapasitas UMKM melalui sharing database, sharing market dan lain-lain. O'Samawa juga menjalin kerja sama dengan BAPPEDA Kabupaten Sumbawa dalam hal Penelitian dan Perencanaan Program. Sementara itu peran bisnis lebih utama adalah pihak bank dan rumah kreatif BUMN. Ada-pun peran bank adalah sebagai mentorship, menyiapkan modal pinjaman dan hibah. Bentuk-bentuk kerja sama nyata yang sudah dilakukan O’Samawa adalah: 
Training dari pelaku Start up dan Bank ke UMKM, Kerja sama antara bank dengan UMKM untuk pinjaman kemitraan dengan bunga 3 persen, Kerjasama marketing, kami punya tempat di gedung UPT. Batik untuk centre UMKM jualan, Kerja sama dengan pemda dalam hal ini diskoperindag untuk akselerasi UMKM melalui sharing database, sharing market dan lain-lain (J A, Universitas Teknologi Sumbawa)

Substansi yang ingin dikejar O'Samawa adalah Kabupaten Sumbawa yang mandiri pangan 2020 (DD, Bappeda Sumbawa). Bila mandiri pangan yang ditargetkan maka O'Samawa perlu mempertimbangkan substitusi impor, dengan memproduksi produk primer dalam masyarakat. Biasanya UMKM menghasilkan produk sekunder berupa oleh-oleh yang bukan merupakan kebutuhan pokok konsumen. Reorientasi produksi UMKM dari produk yang biasa dikerjakan menjadi produk kebutuhan mendasar konsumen sehingga perlu menjadi salah satu blue print pencapaian ke depan. Karena umumnya kebutuhan primer masyarakat lokal lebih dominan dihasilkan perusahaan besar di pusat.

\section{Melakukan Transformasi}

Setiap inovasi adalah pekerjaan dinamis, konten dan cara kerjanya terus berjalan sesuai jaman dan kebutuhan. Dengan demikian perencana inovatif harus memberi ruang secara fleksibel unsurunsur pendukung di dalamnya untuk berubah. Demikian pula dengan inovasi di Sumbawa, institusi yang melahirkan inovasi diberi ruang untuk dapat berubah bentuk (transformasi). Salah satu langkah membesarkan Lembaga itu, dengan penggabungan berbagai unsur yaitu lembaga sekaligus sumber daya manusia di dalamnya. Atas dasar itu, O`Samawa yang lahir di tahun 2018 harus bertransformasi untuk mencapai kelembagaan yang lebih luas.

Menurut DD, O`Samawa bertransformasi menjadi Akselerator Bisnis.

"Sekarang ini didirikan akselator bisnis samawa, terdiri dari O Samawa dengan Jihan sebagai penggagas, berkaitan dengan dengan komunitas Irwandi dan peningkatan kapasitas agus salam. Akeselator Bisnis ada pengelolanya, yaitu kordinator, ada devisi komunitas, devisi networking dan peningkatan kapasitas. Bila ada aktifitas seringkali libatkan mahasiswa. Di samping itu, ada partisipasi perbankan dan pengusaha local"

Akselarator bisnis yang merupakan kumpulan dari berbagai inovator, termasuk O'Samawa telah membangun kerja sama dengan berbagai pihak dengan ditandatanganinya MOU triple helix, terdiri dari Universitas Teknologi Sumbawa (UTS), UMKM, Bappeda Kabupaten Sumbawa, Dinas Koperasi. Menurut Dedy baru-baru ini telah dibina sekitar 10 start up yang dibina oleh Akselarator Bisnis, mereka bergerak di bidang kuliner, fashion, pengolahan sampah, kerajinan tangan dan lain-lain.

Akselator bisnis hadir untuk melakukan pendampingan dan perkuat jaringan usaha-usaha yang ada namun terkendala modal, kapasitas (skill), jaringan dan pasar sehingga mampu untuk survive. Dengan demikian, produk-produk lokal di Sumbawa dapat dikenal oleh masyarakat dengan berbagai upaya pemasaran baik dengan sesama jaringan maupun di media-media social. Selama ini masalah utama dari usaha lokal adalah kapasitas pasar yang terbatas.

O`samawa saat ini telah berganti dengan akselarator bisnis. Namun model triple helix tetap menjadi landasan kerja sama antar pemangku kepentingan.

\section{Beberapa Kendala Pengembangan}

Kendala yang dihadapi O'samawa atau yang berganti lembaga akselarasi bisnis adalah pemangku kepentingan di dalamnya belum fokus membesarkan. O'Samawa belum dianggap sebagai pekerjaan utama, melainkan sebagai sambilan. Misalnya ada star-tup yang merupakan mahasiswa ikut komunitas hanya sebagai sambilan semata. Di samping itu, belum terkreasinya kelembagaan (the rule of the game) terkait peran yang jelas dan berkelanjutan dari masing-masing pihak di dalamnya. Di samping itu, gaung dari O'Samawa belum cukup luas, hal ini dibuktikan 
rendahnya O'Samawa dibahas dalam media-media online baik kabupaten Sumbawa lebih-lebih di luar daerah.

Ada banyak hal yang perlu diperbaiki untuk menyempurnakan konsep yang telah dibangun ini. Misalnya meningkatkan keberpihakan anggaran pemerintah daerah untuk memajukan kelembagaan dalam bentuk litbang, penguatan penggunaan teknologi informatika (Nielsen, 2018) sehingga jangkauan produk yang lebih meluas.

Penguatan SDM yang mengelola O'Samawa perlu ditingkatkan, khususnya di bidang IT yang menjadi core dari industri saat ini. Apa yang dilakukan Jepang dapat dicontoh, pemerintah Jepang terus mempromosikan sinergi antara akademisi dan industri dengan memberi dana kolaboratif pada litbang kolaboratif antar industri dan kampus setempat, memfasilitasi R\&D, membeli peralatan penelitian dan sebagainya. Bahkan di tengah-tengah difisit anggaran pemerintah tetap anggarkan untuk pemeliharaan pusat teknologi lokal atau local technology center (TC) yang dihajatkan untuk membantu usaha kecil dan menengah (Nozawa, 2014).

\section{KESIMPULAN DAN SARAN}

Setidaknya ada empat inovasi yang dilahirkan Kabupaten Sumbawa yaitu Pariri Si Desa, Si Andini, Si Jinak dan O'Samawa. O'Samawa merupakan model triple helix yang lahir berdasar MoU antara Pemerintah Kabupaten Sumbawa diwakili Bappeda, Universitas Teknologi Sumbawa dan Pelaku Usaha. Tujuan dari O'Samawa adalah membantu pelaku usaha untuk mengembangkan kapasitas produksi dan jaringan pasar. Kegiatan yang telah dilakukan adalah berupa training pengembangan bisnis, membangun koneksi antara pelaku usaha dan perbankan, perbaikan kualitas produk dan kemasan, membuka gerai (tempat penjualan) secara kolektif dan membangun pasar online. Saat ini O'samawa telah bertransformasi menjadi akselarasi bisnis, dengan pola triple helix yang sama. Kendala yang dihadapi pengembangan triple helix adalah pelaku usaha dalam komunitas belum menjadikan bisnis ini sebagai pekerjaan utama. Umumnya triple helix dianggap sebagai pekerjaan sampingan oleh sebagian pelakunya.

Penelitian ini memberi tambahan pengetahuan secara empiris, di mana untuk mendesain inovasi dibutuhkan suasana santai. Tidak dibalut sekat-sekat birokrasi. Di samping itu, kerja sama lintas sektor dalam model triple helix dibutuhkan format saling menguntungkan (bisnis oriented) sehingga masing-masing dapat merawat kerja sama triple helix.

Diperlukan kajian lanjutan, terutama terkait strategi mengawetkan inovasi, misalnya menentukan pola hubungan yang efisien antara riset perguruan tinggi yang mahal dan penerapan di dunia industri yang praktis. Di samping itu penelitian terkait yang perlu dilakukan ke depan adalah desain institutional arrangements (tata kelambagaan) dalam bentuk model organisasi dan tata aturan triple helix. Sehingga pihak-pihak yang bekerja sama merasa saling menguntungkan dan kerja sama triple helix dapat lebih awet ke depan.

\section{REFERENSI}

Alamsyah, A., \& Fitriah, M. (2009). Strategi komunikasi pelayanan publik melalui program pos pemberdayaan keluarga. Jurnal ASPIKOM, 3(2).

Altaf, A., Hassan, I. e, \& Batool, S. (2019). The role of ORIC in the evolution of the triple helix culture of innovation: The case of Pakistan. Technology in Society, 56.

Carbonara, N., \& Pellegrino, R. (2018). Fostering innovation in public procurement through public private partnerships. Journal of Public Procurement, 18(3).

Ella, S., \& Utami, I. R. (2017). Sistem Informasi Penilaian (SIP) Bdg Juara: Sebuah Inovasi Untuk Meningkatkan Pelayanan Publik. Jurnal Penelitian Komunikasi, 20(2).

Etzkowitz, H. (2017). The Triple helix: University-Industry-Government Innovation and 
Entrepreneurship (2nd editio). New York: Routledge.

Etzkowitz, H., \& Zhou, C. (2017). The triple helix: University-industri-government innovation and entrepreneurship. The Triple helix: University-Industri-Government Innovation and Entrepreneurship. https://doi.org/10.4324/9781315620183

Guerrero, M., \& Urbano, D. (2017). The impact of Triple helix agents on entrepreneurial innovations' performance: An inside look at enterprises located in an emerging economy. In Technological Forecasting \& Social Change, 119.

Hill, P. S., Goeman, L., Sofiarini, R., \& Djara, M. M. (2014). 'Desa SIAGA', the 'Alert Village': the evolution of an iconic brand in Indonesian public health strategies. Health Policy \& Planning, 29(4).

Hughes, T. (2014). Co-creation: moving towards a framework for creating innovation in the Triple helix. Prometheus (United Kingdom), 32(4), 337-350. https://doi.org/10.1080/08109028.2014.971613

Hutagalung, S. S., \& Hermawan, D. (2018). Evaluation of Local Government Innovation Program in Lampung Province. Jurnal Bina Praja, 10(2).

Jauhiainen, J. S., \& Suorsa, K. (2009). Triple helix in the periphery: The case of Multipolis in Northern Finland. Nordia Geographical Publications, 38(4), 285-301. https://doi.org/10.1093/cjres/rsn009

Leydesdorff, L., Perevodchikov, E., \& Uvarov, A. (2015). Measuring Triple-Helix Synergy in the Russian Innovation Systems at Regional, Provincial, and National Levels. Journal of The Association For Information Science And Technology, 66(6), 1229-1238. https://doi.org/10.1002/asi

Mahalul, Z., H, O. W. K., \& Sugiharto. (2018). Pos Informasi Leptospirosis Di Kawasan Air Rob. Rekayasa Vol., 16(2), 219-228.

Mei, C., \& Wang, X. (2017). Political Incentives and Local Policy Innovations in China. Journal of Chinese Political Science, 22(4), 519-547. https://doi.org/10.1007/s11366-017-9513-8

Nelson, K. L., \& Svara, J. H. (2012). Form of Government Still Matters: Fostering Innovation in U.S. Municipal Governments. American Review of Public Administration, 42(3).

Nielsen, M. M. (2018). eGovernance frameworks for successful citizen use of online services: A Danish-Japanese comparative analysis. JeDEM - EJournal of EDemocracy and Open Government, 9(2), 68-109. https://doi.org/10.29379/jedem.v9i2.462

Nozawa, K. (2014). Unzip the Triple helix Application of Regional Triple helix in Japan. Triple helix, 3(1).

Oganisjana, K., \& Gvatua, S. (2017). Barriers to Social Innovation and Ways of Overcoming Them in Latvia, 15(5), 33-38.

Paskaleva, K., \& Cooper, I. (2018). Open innovation and the evaluation of internet-enabled public services in smart cities. Technovation, 78 .

Pique, J. M., Berbegal-Mirabent, J., \& Etzkowitz, H. (2018). Triple helix and the evolution of ecosystems of innovation: the case of Silicon Valley. Triple helix, 5(1). https://doi.org/10.1186/s40604-018-0060-x

Reich-Graefe, R. (2016). Intermediation in intermediation: triple helix innovation and intermediary legal organisation. Triple helix, 3(1).

Rri. (2018, July 12). Program Inovasi "Pariri Si Desa” Kecamatan Lantung, Masuk Top 99 KIPP 
Nasional.

Sabry, M. I. (2018). State business relations and innovation in the MENA region. Middle East Development Journal, 10(2).

Sato, S. (2017). Climate change, the built environment and triple-helix innovation. Leveraging Energy Technologies and Policy Options for Low Carbon Cities, Energy Procedia, 143.

Smith, H. L., \& Leydesdorff, L. (2017). The Triple helix in the context of global change: dynamics and challenges. $\quad$ Prometheus, 32(4), 321-336. https://doi.org/10.1080/08109028.2014.972135

SuaraNTB. (2018, December 21). Luncurkan Sumbawa Smart City di HUT Sumbawa, Sejumlah Aplikasi akan Diperkenalkan. SuaraNTB. Retrieved from https://www.suarantb.com/headline/2018/12/264783/Luncurkan.Sumbawa.Smart.City.di. HUT.Sumbawa,Sejumlah.Aplikasi.akan.Diperkenalkan/

Tiza, A. L., Hakim, A., \& Haryono, B. S. (2014). Implementasi Program Pembangunan Desa Mandiri Anggaran Untuk Rakyat Menuju Sejahtera (Anggur Merah) (Studi di Badan Perencanaan Pembangunan Daerah Kabupaten Timor Tengah Utara). Wacana, 17(2), 5867.

Verlinde, S., \& Macharis, C. (2016). Innovation in Urban Freight Transport: The Triple helix Model. Transportation Research Procedia, 14.

Wang, J. (2018). Innovation and government intervention: A comparison of Singapore and Hong Kong. Research Policy, 47(2).

Yarime, M. (2018). Japan's Experience of Creating Innovation for Smart Cities : Implications for Public Policy for Urban Sustainability. 